\title{
INVESTMENT RISK IN WIG30 BANK SECTOR STOCKS - ASSESSMENT OF THE APPLICABILITY OF THEORETICAL MEASUREMENT METHODS
}

\author{
KAMILA BEDNARZ-OKRZYŃSKA
}

University of Szczecin, Faculty of Management and Economics of Services, Department of Quantitative Methods, Szczecin, POLAND e-mail: kamila.bednarz@wzieu.pl

\begin{abstract}
RECEIVED
5 August 2017

ACCEPTED

12 December 2017

JEL

CLASSIFICATION

D53, G11

KEYWORDS

risk measures, stock companies, empirical distributions, rate of return

ABSTRACT

This paper analyzes the investment risk in WIG30 bank sector stocks based on the period of 3 years from 30.05.2014 to 31.05.2017. As a part of the investment risk analysis the following were determined: basic descriptive distribution parameters, the probability of loss, beta coefficient and interrelated market risk and full risk. Furthermore, the risk-profit graph was created, and the coefficient of relative profit was determined. The aim of this paper is to determine certain measures of investment risk and to compare the scope of their applicability. An additional aim is to assess the applicability of theoretical distributions - the Gaussian, Laplace and GED - in modelling empirical distributions of return rates on WIG30 bank sector stocks.
\end{abstract}

\section{Introduction}

One of the fundamental issues inherent in gaining financial success is the ability to manage one's own capital. The most effective way of such management is investment. However, each and every investment is burdened with uncertainty and risk. The same holds for investing in bank sector companies, the importance of which for the Polish economy is common knowledge. And despite a noticeable decline of trust in this sector in recent years, 
hardly any boom on the Polish stock exchange can be reported without strong bank stocks. Therefore, investing in the Warsaw stock market bank stocks has long been an object of interest of both stock market players and researchers (Chorkowy, Drymluch, 2008; Konarzewska, 2017; Feder-Sempach, 2011; Płowaś, 2015; Pośpiech, Mastalerz-Kodzis, 2015).

Investment decisions concerning the choice of stocks in which one wants to invest, should be preceded by the analysis of both the profitability and risk. The risk analysis based on historical data enables the application of risk measures based on statistical analysis. Along the same lines, risk measures can be divided into three basic categories: variability measures, uncertainty measures and sensitivity measures.

The classic and, at the same time, the oldest group of risk measures are variability measures. They describe the degree of dispersion of return rates around an expected value or a mean value. Sensitivity measures describe how much return rates on investment can be affected by risk factors. The aim of the sensitivity measures is to capture the relation between the value of the financial instrument and the risk factors which directly impact the value of the instrument in question.

This paper analyzes the investment risk in WIG30 bank sector stocks. In order to examine the most up-to-date data, the period of three years from 30.05.2014 to 31.05.2017 was applied. Precisely, there were three periods: Period I 31.05.2016-31.05.2017 (252 observations), Period II 29.05.2015-31.05.2017 (503 obs.) and Period III 30.05.2014- 31.05.2017 (751 obs.).

Index WIG30 has been published since 23 Sept 2013, based on the value of portfolio with shares in 30 largest and most fluid companies at the Warsaw Stock Exchange. WIG30 may contain the maximum of 7 companies representing a certain stock market sector and the share of one company may comprise the maximum of 10 percent of the index. Due to the former restriction, in the analysis of Period III, index WIG30 at first comprised Bank Handlowy, which since 19.02.2016 has been replaced by Bank Millennium. Hence both banks were included in this paper. This means that the following companies were analyzed in this work: ALIOR, BZWBK, HANDLOWY, INGBSK, MBANK, MILLENNIUM, PEKAO, PKOBP.

In the analysis of investment risk the following were determined: basic descriptive distribution parameters, the probability of loss, beta coefficient, interrelated market risk and full risk. Furthermore, the risk-profit graph was created, and the coefficient of relative profit was determined.

The aim of this paper was to determine certain measures of investment risk and to compare the scope of their applicability. Another aim was the assessment of applicability of theoretical distributions - the Gaussian, Laplace and GED - in modelling empirical distributions of return rates on WIG30 bank sector stocks.

\section{Remarks about applied methods}

For modeling the empirical return rates, the estimation of theoretical distribution parameters had to be carried out. For the Gaussian distribution, the parameter estimation was made by means of MLM (Maximum Likelihood Method). For the Laplace distribution, 3 methods were applied: MLM, the modified MLM, which consists in estimating the location parameter by means of the mean value, and the method of moments. For GED (Generalized Error Distribution), 3 methods of parameter estimation were used: MLM, approximation with the method of moments (Krupiński, Purczyński, 2006) and approximated moment method (Purczyński, Bednarz, 2014). The evaluation of the applicability of the theoretical distribution was performed by means of the chi square test. To determine the probability of loss, the above theoretical distributions were applied. 


\section{Basic descriptive parameters}

Table 1 includes the basic descriptive statistics of the series under study. The following statistics were analyzed: average daily return (column 3), range, the difference between the largest and smallest value of return rate in the considered period (col 4), kurtosis (col. 5), skewness (col. 6), standard deviation (col. 7), semi standard deviation (col. 8) and relative profit (ratio of income to risk) (col. 9). It should be noticed that some of these statistical characteristics are useful tools for preliminary evaluation of the return rate distribution.

Table 1. Descriptive parameters of distributions of return rates onWIG30 bank sector stocks

\begin{tabular}{|c|c|c|c|c|c|c|c|c|}
\hline Company & Period & Ret. rate & Range & Kurtosis & Skewness & Standard dev. & $\begin{array}{l}\text { Semis.dev } \\
\sqrt{2} \times \text { SV }\end{array}$ & Rel. profit \\
\hline 1 & 2 & 3 & 4 & 5 & 6 & 7 & 8 & 9 \\
\hline & 1 & 0.001342 & 0.1771 & 2.108 & 0.416 & 0.02193 & 0.02074 & 0.0612 \\
\hline \multirow[t]{3}{*}{ ALIOR } & $\|$ & -0.000354 & 0.2936 & 11.655 & -1.036 & 0.02266 & 0.02344 & -0.0156 \\
\hline & III & -0.000048 & 0.2936 & 11.162 & -0.864 & 0.02086 & 0.02132 & -0.0023 \\
\hline & 1 & 0.001279 & 0.1254 & 1.037 & 0.520 & 0.01965 & 0.01839 & 0.0651 \\
\hline \multirow[t]{3}{*}{ BZWBK } & ॥ & 0.000223 & 0.1436 & 0.874 & 0.246 & 0.02135 & 0.02073 & 0.0104 \\
\hline & III & 0.000095 & 0.1458 & 1.110 & 0.167 & 0.01980 & 0.01943 & 0.0048 \\
\hline & 1 & -0.000059 & 0.1302 & 0.564 & -0.160 & 0.02063 & 0.02083 & -0.0029 \\
\hline \multirow[t]{3}{*}{ HANDLOWY } & ॥ & -0.000651 & 0.1584 & 1.457 & -0.276 & 0.02191 & 0.02227 & -0.0297 \\
\hline & III & -0.000523 & 0.1584 & 2.005 & -0.299 & 0.02002 & 0.02036 & -0.0261 \\
\hline & 1 & 0.001590 & 0.1057 & 1.109 & 0.015 & 0.01558 & 0.01544 & 0.1021 \\
\hline \multirow[t]{3}{*}{ ING BŚ } & ॥ & 0.000556 & 0.1296 & 1.083 & 0.060 & 0.01811 & 0.01796 & 0.0307 \\
\hline & III & 0.000393 & 0.1290 & 1.423 & 0.029 & 0.01662 & 0.01656 & 0.0236 \\
\hline & 1 & 0.001544 & 0.2039 & 3.243 & 0.533 & 0.02280 & 0.02157 & 0.0677 \\
\hline \multirow[t]{3}{*}{ MBANK } & II & 0.000101 & 0.2039 & 2.184 & 0.331 & 0.02245 & 0.02166 & 0.0045 \\
\hline & III & -0.000003 & 0.2039 & 2.493 & 0.284 & 0.02063 & 0.01999 & -0.0001 \\
\hline & 1 & 0.001955 & 0.2588 & 11.047 & 1.608 & 0.02378 & 0.02047 & 0.0822 \\
\hline \multirow[t]{3}{*}{ MILLENNIUM } & ॥ & 0.000221 & 0.2956 & 8.330 & 0.493 & 0.02336 & 0.02233 & 0.0095 \\
\hline & III & 0.000036 & 0.2956 & 6.787 & 0.166 & 0.02289 & 0.02256 & 0.0016 \\
\hline & 1 & -0.000177 & 0.1224 & 1.950 & -0.174 & 0.01616 & 0.01642 & -0.0110 \\
\hline \multirow[t]{3}{*}{ PEKAO } & ॥ & -0.000462 & 0.1224 & 0.749 & -0.047 & 0.01710 & 0.01716 & -0.0270 \\
\hline & III & -0.000263 & 0.1224 & 0.739 & -0.067 & 0.01615 & 0.01625 & -0.0163 \\
\hline & 1 & 0.001733 & 0.1723 & 3.296 & 0.748 & 0.01962 & 0.01800 & 0.0883 \\
\hline \multirow[t]{3}{*}{ PKO BP } & ॥ & 0.000407 & 0.1782 & 2.159 & 0.251 & 0.01934 & 0.01880 & 0.0210 \\
\hline & III & 0.000017 & 0.1782 & 2.540 & 0.208 & 0.01784 & 0.01740 & 0.0010 \\
\hline & I & 0.001116 & 0.0716 & 2.320 & -0.433 & 0.00908 & 0.00936 & 0.1229 \\
\hline \multirow[t]{3}{*}{ WIG } & II & 0.000205 & 0.0871 & 2.859 & -0.538 & 0.00979 & 0.01018 & 0.0209 \\
\hline & III & 0.000231 & 0.0871 & 3.033 & -0.487 & 0.00897 & 0.00928 & 0.0258 \\
\hline & 1 & 0.001122 & 0.0778 & 1.320 & -0.182 & 0.01069 & 0.01079 & 0.1050 \\
\hline \multirow[t]{2}{*}{ WIG 30} & $\|$ & 0.000033 & 0.0951 & 1.772 & -0.291 & 0.01138 & 0.01162 & 0.0029 \\
\hline & III & 0.000067 & 0.0951 & 2.049 & -0.269 & 0.01036 & 0.01054 & 0.0065 \\
\hline
\end{tabular}

Source: author's own study.

The presented measures were derived on the basis of the formulas included in paper (Tarczyński, Mojsiewicz, 2001; Tarczyński, 2002). Range is a measure which helps to evaluate the equity risk in a relative way. By interpreting the range, one may say that the widest interval containing the return rate means potentially the chance for the 
largest profit, but also the highest risk. The data presented in the table shows that in Periods II and III, the widest range was obtained by the return rates on MILLENNIUM, ALIOR and MBANK stocks.

Kurtosis is a measure which describes the unevenness of the lay-out of the general sum of values among particular individuals. By determining the mean of kurtosis, we obtained $K=3.157$. This value is closer to the kurtosis for the Laplace distribution, $K L=3$, than to the kurtosis for the normal distribution, $K N=0$. Hence it can be concluded that the Laplace distribution will be more useful in modeling empirical distribution of return rates on stocks and indices than the Gaussian distribution. Considering Col. 3 for Period I, the companies may be arranged in decreasing order of the value of the average daily return: MILLENNIUM, PKOBP, INGBSK, MBANK, ALIOR, BZWBK, HANDLOWY, PEKAO. However, for Period III the following sequence can be observed: INGBSK, BZWBK, MILLENNIUM, PKOBP, MBANK, ALIOR, PEKAO, HANDLOWY.

As for the risk measured with the value of the standard deviation, for Period I, the sequence of the companies in order of increasing value $\sigma$ is as follows: INGBSK, PEKAO, PKOBP, BZWBK, HANDLOWY, ALIOR, MBANK, MILLENNIUM. For Period III the sequence of the companies in order of increasing $\sigma$ is as follows: PEKAO, INGBSK, PKOBP, BZWBK, HANDLOWY, MBANK, ALIOR, MILLENIUM.

Standard deviation is a basic measure of the risk of investment in securities. As regards the standard deviation of stocks, risk is determined by deviations of possible returns from expected returns. When adopting this way of risk evaluation, positive and negative deviations are equally treated. Therefore a more precise measure used to determine risk is semi standard deviation, which indicates how much possible returns deviate on average from expected returns as a result of unfavorable market situations.

Comparison of standard deviations with semi standard deviations derived for the same data may serve as the information whether the distribution of the analyzed return rates is symmetrical. If the return rate distribution is symmetrical, the standard deviation is larger the square root of 2 times than the semi standard deviation. In the case of a symmetrical distribution, there is a larger probability that the distribution of the return rate on a security is normal or close to normal.

Skewness coefficient informs about a degree and direction of the skewness of the distribution. It takes the value of zero for the symmetric distribution, negative values for the left skewed distribution, and positive values for the right skewed one. The right skewed distribution is beneficial for investors since it denotes larger probability of a higher return rate than the average value determined for the whole project (Bednarz-Okrzyńska, 2016).

\section{Modeling empirical return rates}

As a result of calculations, it was observed that for the thirty cases included in Table 1, the positive result of the chi-square test was obtained: for the normal distribution - 17 times, for the Laplace distribution - 23 times, and for the GED - 25 times. This means that the Laplace distribution is more useful in modeling the empirical distribution of return rates on bank sector stocks than the Gaussian one. Still GED proved slightly better than the Laplace distribution.

Due to the publishing limitations imposed on the paper, the results are not presented in the form of a table.

\section{Beta coefficient and equity risk based on the Sharpe model}

A classic tool used in risk analysis is the Sharpe model (Tarczyński, Witkowska, Kompa, 2013). 
In the model, a linear regression of the following form is assumed:

$$
R_{t}=a+\beta \times R W_{t}+\varepsilon_{t},
$$

where:

$R_{t}-$ return rate for a stock,

$\mathrm{RW}_{\mathrm{t}}-$ WIG index return rate,

a, $\beta$ - coefficients,

$\varepsilon_{t} \quad$ - random element.

The above formula shows that if return rate $R W_{t}$ increases by $1 \%$, return rate $R_{t}$ increases by $\beta \%$.

From Table 2 the highest value of the coefficient $\beta=1.497$ can be found for MILLENNIUM. This means that the change in the value of the return rate of WIG index by $1 \%$ results in the change in the value of the return rate for a given stock by $1.497 \%$. If $\beta>1$ than the stock is aggressive and if $\beta<1$ than the stock is defensive. The table shows that only one stock is defensive, that is INGBSK where $\beta=0.8952$. All the other stocks are aggressive. The smallest value of $\beta$ characterizing INGBSK results in the smallest value of the market risk (see Table 2). Respectively, the highest value of $\beta$ for MILLENNIUM results in the highest value of the market risk (Table 2).

Table 2. The beta coefficient and equity risk based on the Sharpe model

\begin{tabular}{lccccc}
\hline \multicolumn{1}{c}{ Company } & $\begin{array}{c}\text { Coefficient } \\
\beta\end{array}$ & Market risk & Specific risk & Total equity risk & $\begin{array}{c}\text { Coeff. of determination } \\
\rho^{2}\end{array}$ \\
\hline \multicolumn{1}{c}{1} & 4 & 5 & 6 & 7 & 8 \\
\hline ALIOR & 1.2246 & 0.01098 & 0.01775 & 0.02088 & 0.278 \\
BZWBK & 1.4283 & 0.01281 & 0.01511 & 0.01982 & 0.419 \\
HANDLOWY & 1.3025 & 0.01168 & 0.01628 & 0.02004 & 0.341 \\
ING BS & 0.8952 & 0.00803 & 0.01458 & 0.01665 & 0.233 \\
MBANK & 1.4361 & 0.01288 & 0.01613 & 0.02064 & 0.390 \\
MILLENNIUM & 1.4970 & 0.01343 & 0.01856 & 0.02291 & 0.345 \\
PEKAO & 1.1714 & 0.01051 & 0.01227 & 0.01616 & 0.424 \\
PKO BP & 1.4630 & 0.01312 & 0.01209 & 0.01785 & 0.542 \\
WIG 30 & 1.1422 & 0.01025 & 0.00148 & 0.01036 & 0.980 \\
\hline
\end{tabular}

Source: author's own study.

\section{Risk-profit glaph}

Another classic tool used in risk analysis is a risk-profit (R-P) graph. Figure 1 depicts such an R-P graph for Period III (fig. on the left) and for Period I (figure on the right) including the five companies which turned out best in the R-P graph. The following labelling was used for average daily return: EW-WIG, EBZ-BZWBK, EING-INGBSK, EMB-MBANK, EMIL-MILLENNIUM, EPKO-PKOBP.

Analogous labeling was applied for standard deviation $\sigma$. 

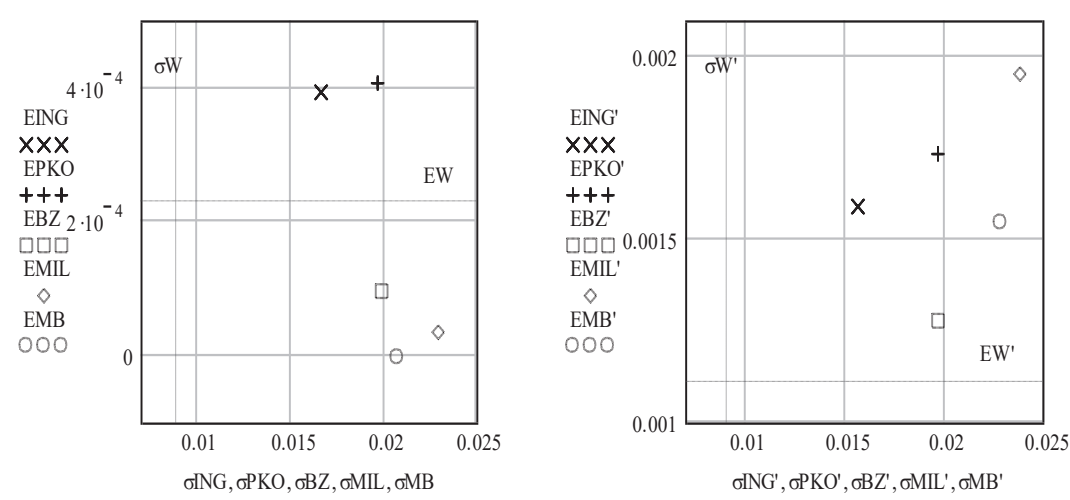

Figule 1. R-P graph for the following companies: INGBSK, PKOBP, BZWBK, MILLENNIUM, MBANK

Source: author's own study.

Figure 1 on the left refers to Period III (3 years). INGBSK (marked with $\mathrm{x}$ ) turns out to be the most profitable - the mean is slightly smaller than that of PKOBP (marked with +), but its standard deviation is significantly smaller. Out of the other three companies, the largest profit is provided by BZWBK (marked with rectangles). The last two companies hold a similar position: MILLENNIUM (diamonds) has a slightly larger profit at a slightly higher risk than MBANK (circles). Figure 1 on the right refers to Period I (a year). MILLENNIUM could be recommended to people fond of risk, since it provided the highest profit but at the highest risk. The next company, INGBSK, in comparison with the former one, brings smaller profit but at the substantially smaller risk, so it could be recommended to people who like to play it safe. The two subsequent companies are: PKOBP and MBANK. The smallest profit is brought by the stocks of BZWBK.

According to the figures representing R-P graphs, the location of a company depends on two variables: mean and standard deviation of a return rate. The parameter which takes into account these two variables is the coefficient of relative profit, given by the formula (Tarczyński, Mojsiewicz, 2001):

$$
\mathrm{W}=\mathrm{E} / \sigma \text {. }
$$

By sequencing the companies in order of decreasing value of relative profit coefficient (Table 1, col. 9), a similar sequence to the one resulting from the R-P graph is obtained.

This means that instead of making R-P graphs, the evaluation of companies can be made in a much simpler way, namely, by using the relative profit coefficient.

\section{Conclusions}

As a part of the analysis of the results presented in Table 1, the companies were sequenced in order of increasing value of standard deviation sigma. By taking into account that sigma is quite stable and is a certain characteristic feature of a company (it should be assumed that it will not change significantly within the following year), it can be used to describe companies in terms of a small or high risk. However the R-P graph, apart from standard deviation, includes also the mean value of return rate (profit). Conclusions, similar to those based on the $\mathrm{R}$-P graph, can be also drawn from the analysis of the relative profit coefficient. The results presented in Table 2 show that the only bank that proved to be a defensive company was INGBSK $(\beta=0.8952<1)$. All the other banking 
companies proved to be aggressive $(\beta>1)$. Thereby INGBSK ensures the smallest market risk among all the companies under study. Hence, the company is recommended to cautious investors.

As a part of the analysis of risk measurement tools, the probability of loss was determined for the bank sector companies as the integral of the probability density function of the theoretical distributions: Gaussian, Laplace and GED. Yet it would be unlikely to recommend this risk measure to an investor in bank sector companies for two reasons: calculations involve determining the value of an integral, and the diversity of the determined values is limited. For example, for the eight companies under study the probability of loss fell within the interval [0.427; 0.532$]$, which results in the ratio of the highest value to the smallest one equal 1.246. However the standard deviation fell within $[0.01558 ; 0.2378]$, hence $\mathrm{max} / \mathrm{min}=1.526$. Still larger differentiation can be observed for $\beta \in[0.8952 ; 1.497]$, which amounts to $\mathrm{max} / \mathrm{min}=1.672$.

In view of the conducted study of certain investment risk measures, two measures can be particularly recommended: residual standard deviation and coefficient $\beta$. It stems from a more stable behavior of these measures compared to others.

As a result of modeling empirical distributions of return rates on WIG30 bank sector stocks it was concluded that the Laplace distribution is more useful than the normal one. Besides, slightly better results of approximation of empirical return rate distributions by means of GED were observed, compared to the Laplace distribution. However, considering the computational complexity of estimation of GED parameters, it is advisable to model empirical distributions of return rates on the analyzed stocks by means of the Gaussian or Laplace distributions.

\section{References}

Bednarz-Okrzyńska, K. (2016). Analiza zależności między wartością współczynnika asymetrii a wartością semiodchylenia standardowego stóp zwrotu wybranych indeksów giełdowych i spółek. Studia i Prace WNEiZ US, 1 (45).

Chorkowy, B., Drymluch, M. (2008). Wielowymiarowa analiza porównawcza banków notowanych na Giełdzie Papierów Wartościowych w Warszawie. In: D. Kopycińska (ed.), Konkurencyjność podmiotów rynkowych. Szczecin: Wydawnictwo Katedry Mikroekonomii Uniwersytetu Szczecińskiego.

Feder-Sempach, E. (2011). Ryzyko inwestycyjne. Analiza polskiego rynku akcji. Warszawa: CeDeWu.

Konarzewska, I. (2017). Ryzyko rynkowe inwestycji w akcje na Giełdzie Papierów Wartościowych w Warszawie w latach 2009-2015. Analizy branżowe. Finanse, Rynki Finansowe, Ubezpieczenia, 2 (86).

Krupiński, R., Purczyński, J. (2006). Approximated fast estimator for the shape parameter of generalized Gaussian distribution. Signal Processing, 4 (86).

Płowaś, R. (2015). KNF a kurs akcji spółek bankowych na GPW SA w Warszawie. In: T. Galbarczyk, J. Świderska (eds.), Sektor bankowy wobec wyzwań teraźniejszości. Lublin: Wydawnictwo Uniwersytetu Marii Curie-Skłodowskiej.

Pośpiech, E., Mastalerz-Kodzis, A. (2015). Wielokryterialna ocena banków komercyjnych notowanych na GPW w Warszawie. Zarządzanie i Finanse. Journal of Management and Finance, 3 (13).

Purczyński, J., Bednarz, K. (2014). Estimation of the Shape Parameter of GED Distribution for a Small Sample Size. Folia Oeconomica Stetinensia, 1 (14).

Tarczyński, W. (2002). Fundamentalny portfel papierów wartościowych. Warszawa: PWE.

Tarczyński, W., Mojsiewicz, M. (2001). Zarządzanie ryzykiem. Warszawa: PWE.

Tarczyński, W., Witkowska, D., Kompa, K. (2013). Współczynnik beta. Teoria i praktyka. Warszawa: Wydawnictwo Pielaszek Research.

Cite this article aS: Bednarz-Okrzyńska, K. (2018). Investment risk in WIG30 bank sector stocks - assessment of the applicability of theoretical measurement methods. European Journal of Service Management, 1 (25), 15-21. DOI: 10.18276/ejsm.2018.25-02. 